\title{
Effect of Occupational Safety and Health Awareness on Work Environment in the Water Service Industry within Kisumu County - Kenya.
}

\author{
${ }^{1}$ Ibrahim Oluoch, ${ }^{2}$ Jared O. H. Ndeda, ${ }^{3}$ Paul Njogu, \\ ${ }^{1 \& 3}$ Institute of Energy and Environmental Technology, Jomo Kenyatta University of Agriculture and Technology \\ (JKUAT) P. O. Box 62000-00200 NAIROBI-KENYA \\ ${ }^{2}$ Physics Department, Jomo Kenyatta University of Agriculture and Technology (JKUAT), P.O.Box \\ 62000-00200 NAIROBI-KENYA
}

\begin{abstract}
The study sought to determine effects of occupational safety and health awareness among on work environment in the Kenyan Kisumu County Water Service industry. The study utilized a descriptive research design. The target population consisted of employees of Kisumu Water and Sewerage Company (KIWASCO) and Lake Victoria South Water Service Board (LVSWSB) working in water treatment works, waste water treatment plants and construction sites. From population of 410, Sample size was determined using standard formula by Fisher (1983). Since the population was <10,000, the formula by Mugenda \& Mugenda, (2003) was applied and 81 number of Questionnaires used to obtain primary data finally analyzed using quantitative techniques. A simple random sampling was employed to draw the respondents from each site and selfadministered semi-structured questionnaire was used to acquire data. The data was analyzed using Statistical Package for Social Sciences version 21. Frequencies and percentages were obtained and correlations done using Spearman's correlation coefficients. On the respondents organizations, majority at 57(75\%) worked at KIWASCO, 12(15.79\%) worked at LVSWSB while the minority at 7(9.21\%) worked at GULF. Preponderance of the respondents at 61(80.3\%) were males while the least at 15(19.7\%) females. Most of the respondents at 28(36.6\%) were between 29-39 years of age while the same number of respondents forming the minority at 24(31.6\%) were both between 18-28 years and 40-50 years of ages. Preponderance of the respondents at 61(80.3\%) had attained college level of education as their highest, 9(11.8\%) attained secondary while the minority at 6(7.9\%) had attained primary level of education as their highest. On the number of years worked for the organization, majority at 27(35.5\%) had worked for 4 years, 24(31.6\%) had worked 1 year, 15(19.7\%) had worked for 3 years while the least number of respondents at $10(13.2 \%)$ had worked for 2 years for their organization. Preponderance of the respondents at 49(64.5\%) stated that water supply was their nature of work, 14(18.4\%) stated construction as their nature of work while the minority at 13(17.1\%) stated waste water as their nature of work. This research found that awareness of existence of Safety and Health Act of 2007 was to a large extent, mean $=3.80, S D=1.200$. It was critical for staff to master occupational safety regulations to a large extent, mean $=4.36, S D=0.948$, same applying to the importance of knowing and following safe work procedures mean $=4.49, S D=0.931$. Majority of the respondents were aware of the instructions to follow for safe working practices, mean of 4.38, SD=0.879. The mean of mean was 4.12 denoting that the respondents were aware of occupational safety and health to a large extent. The study analyzed the relationship between staff awareness of occupational safety and health and work environment using Spearman's rho coefficient ,Confidence Level $(C L)=95 \%$, It was established that there is a significant moderate positive relationship between staff awareness of occupational safety and health and work environment in the water service industry in Kisumu County $r(76)=.0363^{* *}, p=0.001$.This meant that by enhancing awareness among staff on the occupational safety and health, the work environment would become more conducive. This may be confirmed by Bandura (1989) that People tend to select activities and associates from the vast range of possibilities in turns of their acquired preferences and competencies. He confirms that the natural and extrinsic effects of their actions in turn, partly determine their thought, patterns and emotional reactions in workplace. This research found that staff was aware of the occupational safety and health provisions at the work place. By enhancing awareness among staff on the occupational safety and health, the work environment in the water sector has comparatively become more conducive. However, awareness creation among staff on OSH has enabled them to be me more conscious and therefore perceive the work environment as not conducive. Further research is necessary to ascertain if improved infrastructure in the water sector under the Water Act 2002 played a role in the improved OSH awareness in the water sector in Kenya.
\end{abstract}

Key words: Occupational health, safety, exposure, Hazards, water service industry, work environment 


\subsection{Background}

\section{Introduction}

According to European Agency for Safety and Health at work (2007), the health of adults of working age affects economic and social development. Recent occupational health data indicate that 40\%-50\%, of the world population is exposed to hazardous conditions in the workplace. It is estimated that approximately 250 million occupational accidents occur worldwide each year, with 335,000 fatalities ILO, (2005) as cited in Thobora \& Thuita, (2015). Hazards at work are in different forms -chemical, physical, biological, psychological and ergonomics. More than 4\% of the world's annual GDP is lost to occupational accidents and disease (ILO, 2001) as cited in Thobora \& Thuita, (2015). Less attention has been given to occupational accidents by injury researchers in Africa.

The healthy workplace concept provides a valuable tool for developing or reinforcing occupational health and safety standards so that conditions continuously improve for the working population. However, a healthy workplace is not only free of hazards, but also provides an environment that is stimulating and satisfying for those who work there. The healthy organization acknowledges all the elements of occupational health and safety in developing policies and programs for the wellbeing of its workers (WHO, 1999).

Abraham Maslow in the hierarchy of needs theory on human motivation used the terms Physiological, Safety, Belongingness and love, Esteem, Self-Actualization and Self -Transcendence needs, to describe the patterns that human motivations generally move through. This study employs the theory of hierarchy of needs on Safety. Safety at work ranks as an important factor in job satisfaction (Kreitner, 2007; Thobora \& Thuita, 2015). It is argued that there has been low compliance to health and safety regulations; where the level of regulation and enforcement of occupational health and safety is grossly inadequate especially when compared to developed countries (Rotich \& Kwasira, 2015). During worker's time they are exposed to various hazards including accidents, noise, dust, vibrations, heat and harsh chemicals among others (Nzuve \& Ayub, 2012).

\subsubsection{The occupational Health and Safety Act 2007}

The occupational Safety and Health Act 2007 aims at securing the safety, health and welfare of workers and the protection of persons other than the workers against the risk to safety and health arising out of, or in connection with the activities of persons at work. The Act sets objectives to promote and improve occupational safety and health standards.

The OSH services in Kenya are governed by two pieces of legislation: the Occupational Safety and Health Act (OSHA), 2007 and the Work Injury Benefits Act (WIBA), 2007. The purpose of OSHA, 2007 is to secure the safety, health and welfare of people at work, and to protect those not at work from risks to their safety and health arising from, or in connection with, the activities of people at work. The purpose of WIBA, 2007 is to provide compensation to employees for work-related injuries and diseases contracted in the course of their employment, and for connected purposes.

Nyakang'o (2016) confirms that more than half of the industrial accidents and injuries in Kenya go unreported. The report estimates that occupational health and safety fatalities and injuries in Kenya for the last five years 2000-2004 are: 1528, 1923, 1332, 1599 and 1387, this was viewed from the background that 11,387 factories and other places of work are registered by the Department of Health and Safety. The report observed that in 2003, mining, construction and transport accounted for $41 \%$ of accidents in Kenya, machine operators and assemblers $28 \%$ while other occupations share $31 \%$ of workplace accidents. From this detail, in relation to age groups $44.4 \%$ of the injuries occurred to persons in the age group of 20 to 29 years, $25 \%$ to the age group of 30 to 39 years and $24 \%$ to the age below 20 years.

According to Manduku and Munjiri (2017), a closer scrutiny of the OSHA, 2007 reveals that many of the dangerous occurrences and prescribed occupational diseases in the $1^{\text {st }}$ and $2^{\text {nd }}$ schedules may exist. There are several instances of unsafe working conditions and work behavior that both employees and employer should place emphasis on. Assets development and operations of water and sanitation facilities are risky assignments for contractors and operators. Health and safety of employees at the workplace in the water industry cannot be underestimated in the wake of increasing risks in sensitive service industries.

In the upcoming technology, social conflicts and terrorism; water infrastructure facilities remain vulnerable and easy points of access to implement acts of terror. Despite the role played by these workers in national development, they are exposed to life threatening challenges like poor working conditions/ environments which may lead to safety and health problems. There is need to establish level of awareness, nature of hazards as practices that influence workplace health and safety in both construction and operations of facilities. This study therefore sought to assess the effect of occupational safety and health awareness on work environment in water service industry. 


\subsubsection{Staff Awareness, Education and Training}

Education and Learning September 2008 report on Literacy's impact on Workplaces Health and Safety by the Conference of Canada showed that low literacy skills can threaten health and Safety in the workplace, "What you don't Know Can Hurt you". A low level of literacy can jeopardize workers safety if they cannot understand the health and safety regulations provided to them. The report states that there is an open inverse relationship between investment in literacy skills and industries requiring high level of health and safety. It explains that many employers are not aware of the impacts of literacy skills on workplace health and safety or productivity.

Education for empowerment can be summarized as an approach to learning that is participatory, is based on real-life experiences, incorporates dialogue between and among educators and workers, critically analyses the organizational and system-wide causes for problems, and has the goals of worker action and empowerment. Education is most effective when it includes the context of behaviors, including an analysis of obstacles to safe work practices. Regulations of training do not include workers' right to act. Empowerment education may differ from other training programs which focus on training workers to follow safe behaviors. Wallerstein et al., 1992 explained that behavioral approach is based on faulty assumptions that people learn better through discrete chunks of knowledge in a linear sequence unlike cognitive emphasis on problem solving, critical thinking capability and one's belief that one can utilize the knowledge learned; and the second assumption that improved behaviors always lead to a safer and healthier workplace. Thobora et al., 2015 explained that employers should ensure employees are protected from hazards at work by ensuring that employees are adequately instructed and trained in safe systems of work such as safe methods for carrying out tasks, safe use of equipments or substances, use of health and safety control measures and personal protective equipments, accident reporting and emergency procedures and their responsibilities for health and safety. Employers are expected to carry out training needs analysis and then provide to employees in appropriate languages: the information, instruction, training and supervision necessary for them to work safely. In identifying training and literacy of the employees, the plant and substances used, hazards identified and risk assessment conducted.

\section{Methodology}

The study utilized a descriptive survey research design. The target populations for this study were 81 number staff working in the clean water treatment, waste water treatment and new project construction sites of LVSWSB and KIWASCO Limited. Descriptive research technique was used as an action strategy to study the current situation in defining the OSH in the water industry. The target population constituted of 60 workers in LVSWSB, 300 in KIWASCO and 50 in Gulf totaling 410 staff. The study used questionnaire, interviews and observation to obtain primary data. Sample size was determined using a sample size standard formula by Fisher (1983).Since the population was less than 10,000, the formula by Mugenda \& Mugenda, (2003) was applied at a confidence level of $95 \%$ or 1.96; $p$ is the proportion in the population estimated to have the desired characteristics (estimated at 0.50). $q$ is $1.0-p$ and $d$ is the degree of accuracy desired (set at 0.05). Authority was secured from both management of LVSWSB and KIWASCO to collect data. Individual participants were sensitized before seeking their consents to freely participate in the research. Questionnaires, observations and photographs were used to collect data. The collected data was analyzed using quantitative techniques. Standard deviation to measure response disparity for the Likert -scale question items was also adapted. The entire hypothesis was tested at $95 \%$ confidence level. Descriptive statistics such as frequencies, percentages, mean and standard deviation were used to describe the characteristics of collected data.

\section{Data Analysis And Findings}

\subsection{Demographic Information}

Table 3.1: Demographic Information

\begin{tabular}{|l|l|l|}
\hline Characteristics & Categories & Percentage/Proportion \\
\hline Respondents organization & LVSWSB & $12(15.79 \%)$ \\
\hline & KIWASCO & $57(75.00 \%)$ \\
\hline Gender of the respondent & GULF & $7(9.21 \%)$ \\
\hline & Male & $61(80.3 \%)$ \\
\hline Age of the respondent & Female & $15(19.7 \%)$ \\
\hline & $18-28$ & $24(31.6 \%)$ \\
\hline & $29-39$ & $28(36.8 \%)$ \\
\hline Respondents Highest level of education & $40-50$ & $24(31.6 \%)$ \\
\hline & Primary & $6(7.9 \%)$ \\
\hline & Secondary & $9(11.8 \%)$ \\
\hline Duration worked with organization & College & $61(80.3 \%)$ \\
\hline & One year & $24(31.6 \%)$ \\
\hline
\end{tabular}


Effect of Occupational Safety and Health Awareness on Work Environment in the Water Service

\begin{tabular}{|l|l|l|}
\hline & Three years & $15(19.7 \%)$ \\
\hline & Four years & $27(35.5 \%)$ \\
\hline Nature of respondents work & Construction & $14(18.4 \%)$ \\
\hline & Water supply & $49(64.5 \%)$ \\
\hline & Waste water & $13(17.1 \%)$ \\
\hline
\end{tabular}

Table 3.2: Awareness on occupational safety and health, and work environment in water service industry in Kisumu County.

The respondents were given statements to react to in 5 point Likert Scale where 1-Strongly Disagree (SD),2Disagree(D), 3-Neutral(N),4-Agree(A) and 5-Strongly Agree(SA).The results were presented in percentages as shown in Table below

\begin{tabular}{|l|l|l|l|l|l|}
\hline Statements & $\mathbf{S D ( \% )}$ & $\mathbf{D}(\%)$ & $\mathbf{N}(\%)$ & $\mathbf{A ~ ( \% )}$ & SA (\%) \\
\hline I am aware of existence of Safety and Health Act of 2007 & $7.9 \%$ & $7.9 \%$ & $11.8 \%$ & $40.8 \%$ & $31.6 \%$ \\
\hline $\begin{array}{l}\text { I have a right to know about any potential hazard to which I may be } \\
\text { exposed at the workplace }\end{array}$ & $5.3 \%$ & $2.6 \%$ & $1.3 \%$ & $25 \%$ & $65.8 \%$ \\
\hline $\begin{array}{l}\text { I have a right to be part of the process of identifying and resolving } \\
\text { workplace health and safety concerns }\end{array}$ & $6.6 \%$ & $1.3 \%$ & $1.3 \%$ & $36.8 \%$ & $53.9 \%$ \\
\hline It is critical for staff to master occupational safety regulations & $2.6 \%$ & $3.9 \%$ & $5.3 \%$ & $31.6 \%$ & $56.6 \%$ \\
\hline It is important to know and follow safe work procedures & $3.9 \%$ & $1.3 \%$ & $2.6 \%$ & $26.3 \%$ & $65.8 \%$ \\
\hline It is important to report injury or illnesses immediately & $1.3 \%$ & $3.9 \%$ & $1.3 \%$ & $19.7 \%$ & $73.7 \%$ \\
\hline Workers should be instructed to follow safe working practices & $1.3 \%$ & $5.3 \%$ & $2.6 \%$ & $35.5 \%$ & $55.3 \%$ \\
\hline I have had a training on occupational health and safety at the workplace & $27.6 \%$ & $17.1 \%$ & $11.8 \%$ & $28.9 \%$ & $14.5 \%$ \\
\hline I have a right to refuse hazardous work & $6.6 \%$ & $3.9 \%$ & $15.8 \%$ & $30.3 \%$ & $43.4 \%$ \\
\hline $\begin{array}{l}\text { In certain circumstances, members of a joint health and safety committee } \\
\text { who are "certified" have the right to stop work that is dangerous to any } \\
\text { worker }\end{array}$ & $7.9 \%$ & $7.9 \%$ & $9.2 \%$ & $31.6 \%$ & $43.4 \%$ \\
\hline $\begin{array}{l}\text { Workers and employers must share the responsibility for occupational } \\
\text { health and safety }\end{array}$ & $6.6 \%$ & $2.6 \%$ & $6.6 \%$ & $36.8 \%$ & $47.4 \%$ \\
\hline
\end{tabular}

\section{Results And Discussion}

Majority of the respondents at 55(42.4\%) were aware of existence of Safety and Health Act of 2007, $12(15.8 \%)$ were unaware of its existence while the least at $9(11.8 \%)$ unsure whether they are aware of the existence of Safety and Health Act of 2007 or not. Majority of the respondents at 69(90.8\%) stated that they had the right to know about any potential hazard to which they may be exposed at the workplace, 6(7.9\%) did not know of this right, while the least number of respondents at 1(1.3\%) were undecided.

This was largely supported by one of the occupational Safety and Health Act of 2007 objectives of informing all persons employed of any risk from new technologies and imminent danger as one of its set objectives in securing the safety, health and welfare of workers and the protection of persons other than the workers against the risk to safety and health arising out of, or in connection with, the activities of persons at work.

A good number of the respondents at $69(90.7 \%)$ were aware that they had a right to be part of the process of identifying and resolving workplace health and safety concerns, 6(7.9\%) were not aware while $1(1.3 \%)$ were uncertain. On the right of decision making in the workplace, this study findings were in convergence with one of the occupational Safety and Health Act of 2007 that ensures that every person employed participates in the application and review of safety and health measures in promotion and improvement of occupational safety and health standards.

Majority of the respondents at $67(88.2 \%)$ were aware that it was critical for staff to master occupational safety regulations, $5(6.5 \%)$ were unaware of this right while $4(5.3 \%)$ were undecided whether it was critical for staff to master occupational safety regulations or not. This finding was largely supported by the occupational Safety and Health Act of 2007 objective that states that arrangements for ensuring safety and absence of risks, to health in connection with the use, handling, storage and transport of articles and substances should be in place with the provision of such information, instructions, training and supervision necessary to ensure the safety and health at work of every person employed so as to promote and improve occupational safety and health standards.

On the knowledge of safe working procedures, majority of the respondents at $70(92.1 \%)$ stated that it was important to know and follow safe work procedures, 4(5.2\%) stated that it was not important to know and follow safe work procedures while the least at $2(2.6 \%)$ were unsure. This representation was in line with a similar study conducted by Thobora et al., 2015 that explains that employers should ensure employees are protected from hazards at work by ensuring that employees are adequately instructed and trained in safe systems of work such as safe methods for carrying out tasks, safe use of equipments or substances, use of health and safety control measures and personal protective equipments, accident reporting and emergency procedures and their responsibilities for health and safety. 
It was popular among $71(93.4 \%)$ of the respondents that it was important to report injury or illnesses immediately, 4(5.2\%) had divergent opinion from opinion from the majority, 1(1.3\%) were not sure.

Preponderance of the respondents at 69(90.8\%) stated that workers should be instructed to follow safe working practices, $5(6.6 \%)$ had divergent opinion from the majority, 2(2.6\%) were undecided. A similar study carried out by Thobora et al., 2015 supported this finding by explaining that employees need to be adequately instructed and trained in safe systems of work such as safe methods for carrying out tasks, safe use of equipments or substances, use of health and safety control measures and personal protective equipments, accident reporting and emergency procedures and their responsibilities for health and safety.

Majority of the respondents at 34(44.7\%) had not undertaken a training on occupational health and safety at the workplace, 33(44.4\%) had been trained on occupational health and safety with the least at $9(11.8 \%)$ being unsure. A similar study findings by Thobora et al., 2015 differed with the study findings by recommending that employees need to be adequately instructed and trained in safe systems of work such as safe methods for carrying out tasks, safe use of equipment or substances, use of health and safety control measures and personal protective equipment, accident reporting and emergency procedures and their responsibilities for health and safety. Employers are expected to carry out training needs analysis and then provide to employees in appropriate languages: the information, instruction, training and supervision necessary for them to work safely. In identifying training and literacy of the employees, the plant and substances used, hazards identified and risk assessment conducted. The study findings was also in divergence with a similar study findings according to Wallerstein \& Weinger, (1992), that revealed that there are three major problems that need to be addressed before the field of worker health and safety education can advance, that is the: the lack of clarity and consensus on the goals of worker education; lack of standards for effective teaching methods, including the lack of skills in these methods of the people who deliver the trainings and inadequacy of program evaluation. Wallerstein et al.,1992 further explains that behavioral approach is based on faulty assumptions that people learn better through discrete chunks of knowledge in a linear sequence unlike cognitive emphasis on problem solving, critical thinking capability and one's belief that one can utilize the knowledge learned; and the second assumption that improved behaviors always lead to a safer more healthful workplace. They concluded that Competency based program which teach skills to perform one's job safely, to the exclusion of a critical understanding of workplace relationships or structures, are on the increase. It was popular among 56(73.7\%) of the respondents to know the right to refuse hazardous work, $12(15.8 \%)$ were unsure while the minority at $8(10.5 \%)$ were not aware of this right.

Majority of the respondents at 57(75\%) were aware that members of a joint health and safety committee who are "certified" had the right to stop work that is dangerous to any worker, $12(15.8 \%)$ were not aware of this right while the minority at $7(9.2 \%)$ were undecided. This was in convergence with a similar study, ( ILO, 2013) that revealed that according to the history of OSH in Kenya that dates back to 1950, it was found necessary to have a legal instrument to manage the safety, health and welfare of people employed in factories. The then colonial government adopted the British Factories Act of 1937 which was later amended in 1990 to the Factories and Other Places of Work Act, in order to enlarge its scope of coverage. In 2007 this Act was repealed, and replaced by the Occupational Safety and Health Act with the enactment of the Work Injury Benefits Act in the same year. Both these laws are administered by the Directorate of Occupational Safety and Health Services (DOSHS). Other legislation that touches on OSH includes the Public Health Act CAP 242, the Environmental Management and Coordination Act (1999), the Radiation Protection Act CAP 243, and the Pest Control Products Act Cap 346. These laws are enforced by different ministries and departments of the Government in managing the safety, health and welfare of employed population.

Preponderance of the respondents at 64(84.2\%) were aware that workers and employers must share the responsibility for occupational health and safety, 7(9.2\%) were not aware while the minority at $5(6.6 \%)$ were undecided.

\subsection{Relationship between awareness on OSH and Work environment}

Table 4.1: Relationship between awareness on OSH and Work environment

\begin{tabular}{|l|l|l|l|l|}
\hline $\begin{array}{l}\text { Analysis } \\
\text { technique }\end{array}$ & Variables & Descriptors & $\begin{array}{l}\text { OSH } \\
\text { Awareness }\end{array}$ & Work Environment \\
\hline \multirow{5}{*}{$\begin{array}{l}\text { Spearman's rho } \\
\text { Awareness OSH }\end{array}$} & $\begin{array}{l}\text { Correlation } \\
\text { Coefficient }\end{array}$ & 1.000 & $.363^{* *}$ \\
\cline { 3 - 5 } & Sig. (2-tailed) &. & .001 \\
\cline { 3 - 5 } & $\mathrm{N}$ & 76 & 76 \\
\cline { 2 - 5 } & \multirow{2}{*}{$\begin{array}{l}\text { Work } \\
\text { Environment }\end{array}$} & $\begin{array}{l}\text { Correlation } \\
\text { Coefficient }\end{array}$ & $.363^{* *}$ & 1.000 \\
\cline { 3 - 5 } & Sig. (2-tailed) & .001 &. \\
\cline { 3 - 5 } & $\mathrm{N}$ & 76 & 76 \\
\hline
\end{tabular}


The study analyzed the relationship between staff awareness of occupational safety and health and work environment using Spearman's rho coefficient ,Confidence Level (CL) $=95 \%$, It was established that there is a significant moderate positive relationship between staff awareness of occupational safety and health and work environment in the water service industry in Kisumu County. This meant that by enhancing awareness among staff on the occupational safety and health, the work environment would become more conducive. This may be confirmed by Bandura, (1989) that People tend to select activities and associates from the vast range of possibilities in turns of their acquired preferences and competencies. He confirms that the natural and extrinsic effects of their actions in turn, partly determine their thought, patterns and emotional reactions in workplace.

\section{Conclusion}

This research found that staff was aware of the occupational safety and health provisions at the work place. By enhancing awareness among staff on the occupational safety and health, the work environment in the water sector has comparatively become more conducive. However, awareness creation among staff on OSH has enabled them to be me more conscious and therefore perceive the work environment as not conducive.

\section{Recommendations}

The management of the water service industry should ensure that staff are sensitized further on occupational safety and health. This will enhance the knowledge of all of them in various aspects and ultimately lead to improved work environment.The perception of water service industry as non conducive is an indication of advanced level of awareness on occupational Safety and Health that seems unique. This could due to heavy investments that have improved water and sanitation infrastructure under water Act 2002. However further research is necessary to ascertain if improved infrastructure played a role in the improved OSH awareness in the water sector in Kenya.

\section{References}

[1] Antonsen, S., Safety Culture: theory, method and improvement, Ashgate Pub Co, Uk, 2009,172

[2] Australian Safety and Compensation Council, National Code of Practice for Induction for Construction Work, 2007.

[3] Bandura,A (1989) Social Cognitive Theory. In R Vasta (Ed) Annals of Child Development. Vol. 6. Six theories of Child Development (pp.1-60). Greenwich, CT JAI Press.

[4] Campbell, A ; All Signs Point to Yes; Literacy’s Impact on Workplace Health and Safety, Ottawa; The Conference Board of Canada. 2008.

[5] European Agency for Safety and Health at Work. Annual Report 2007. Available online at htt://osha.europa.eu

[6] Economic Survey 2011, Kenya National Bureau of Statistics. Available online at http:// www.knbs.or.ke

[7] ILO Conventions. Available online at http://www.ilo.org

[8] ILO, (2013). National Profile on Occupational Safety and Health -Kenya

[9] ILO Code of Practice on Recording and Notification of Occupational Accidents and Diseases (ILO, Geneva, 1996): Available online at http://www.ilo.org

[10] International Corporation Finance, Environmental, Health, and Safety Guidelines for Water and Sanitation, 2007.

[11] James. L,. Choi, C., Ko C., McNeil, K., Minton, K., Wright, A., \& Kim, K. (2008). Organizational and psychosocial climate: A review of theory and research. European Journal of Work and Organizational Psychology, 17, 5-32.

[12] Katsuro, P., Gadzirayi, C. T., Taruwona M \& Mupararano, S. (2010). Impact of Occupational Health and Safety on Worker Productivity; A case of Zimbabwe Food Industry. African Journal of Business Management Volume 4 (13), pp. 2644-2651, 4 October 2010. Available online at http://www.academicjournals.org/AJBM.

[13] Kenya National Bureau of Statistics (2010). The 2009 Kenya Population and Housing Census, Volume 1C.

[14] Kothari, C. R., (2004). Research methodology. Methods and techniques. (2nd ed). New Delhi: New Age International Publishers.

[15] Kreitner, R. (2007). Management. (10 ${ }^{\text {th }}$ ed.) Boston: Houghton Mifflin company

[16] Larcher P \& Sohail M. (1999). Review of Safety in Construction and Operation for the WS\&S Sector: Part 1, London School of Hygiene \& Tropical Medicine, UK WEDC, Loughborough University, UK.

[17] Laws of Kenya, Kenya Law Reports. Available online at http://www.kenyalaw.org

[18] Law, R., Dollard, M., Tuckey,R., \& Dormann, C. (2011). Psychosocial safety climate as a lead indicator of workplace bullying and harassment, job resources, psychological health and employee engagement. Acid. Anal. Prev, 1-12.

[19] Manduku, M.F., Munjuri, M. (2017). Extent of the Implementation of the Occupational Safety and Health Act 2007 in the Sarova Group of Hotels in Nairobi; International Journal Of History And Research Volume 1, Issue 1, pp 1-17, 2017.

[20] Maslow, A., Lowry, R., \& Maslow, B. (1979). The Journal of A. H. Maslow. California: Brooks/Cole.

[21] Mayhew, C., \& Quinlan, M. (2002). Fordism in the Fast Food Industry; Pervasive Management Control and Occupational Health and Safety Risks for Young temporary workers; Blackwell Publishers Ltd / Editional Board 2002 pp 262-284.

[22] Mugenda, O. M. and Mugenda, A. G. (2003).Research Methods: Quantitative and Qualitative Approaches, Acts Press, Nairobi, Kenya

[23] Ng'ang'a, K., Ngigi P., Siboe I., Ongundo D., Wanyona G.,(2013); Health and Safety Conditions at Construction sites in Nairobi County, Kenya.(pp. 336-342).

[24] Nyakong'o, J.B. (2016).Summary Status of Occupational Health And Safety in Kenya. Workshop on the IUPAC-UNIDO Safety Training Program, Part of the IUPAC Congress in Bejing, on Wednesday, August 17

[25] Nzuve, M. \& Ayubu, B. (2012). The Extent of Compliance with Occupational Safety and Health Regulations at Registered Workplaces in Nairobi. International Journal of Business, Humanities and Technology Vol.2 No.2: (pp 115-119).

[26] Occupational Safety and Health Act, 2007. Kenya Gazette Supplement. No 111(Acts No. 15). Available online at http://www.kenyalaw.org 
[27] Rotich, L., Kwasira, J. (2015). Assessment of Success Factors in the Implementation of Occupational Health and Safety Programs in Tea Firms in Kenya: A Case of Kaisugu Tea Factory, International Journal of Economics, Commerce and Management Vol. III, Issue 5, May 2015, (pp. 797-811).

[28] Iavicoli S, Rondinone B, Marinaccio A, Fingerhut M, (2005).Research Priorities in Occupational Safety and Health; A review Article; Industrial Health 2006, 44, 169-178.

[29] Thobora, P., Thuita, S (2015). Assessing the Level of Compliance of Occupational Safety and Health Risk Management Practices with Occupational Safety Legislation in Public TVET Institutions in Nairobi, Kenya, Researchjournalis Journal of Industrial Engineering Vol.1 No.1 May 2015.

[30] Vesely, W.E, Goldberg, F.F, Roberts, H.H, Haasl, R.F. (1981) Fault Tree Hand book. Systems and Reliability Research Office of U.S Nuclear Regulatory Commission, Washington D.C 20555

[31] Wallerstein, N; \& Weinger, M. (1992). Health and Safety Education for Worker Empowerment. American Journal of Industrial Medicine 22: 619-635.

[32] WASREB (2015), Impact Report; Performance Review of Kenya's Water Services Sector 2013-2014, Issue No. 8

[33] Wikipedia, available on http://en.wikipedia.org/wiki/Chernobyl_disaster.

[34] WorkSafeNB, Health \& Safety Orientation Guide for Employees, 2014.

[35] WorkSafe Victoria, Controlling OHS Hazards and Risk. A handbook for workplaces, Edition No.1, November 2007.

[36] World Health Organization. (1999). Regional Guidelines for the Development of Healthy Workplaces. 